\title{
Szociális munka élettörténeti interjú Gosztonyi Gézával
}

B. E.: Kérlek, meséld el a szakmai élettörténetedet!

G. G.: Nagyon örültem, mikor Emő szólt, hogy csinál egy ilyen kurzust.

Mikor szociális munkásként bemutatkozik az ember, akkor mindig mást emel ki. Én korábban építőmérnökként kezdtem dolgozni. Mindig is kitűnő tanuló voltam, ami csak azért érdekes, mert emiatt nem tudtam pályát választani. Édesapám azt mondta, hogy: „Édes fiam, olyan pályát válassz, ami háborúban is jó, békében is jó." Teljesen világos, hogy az ő szándéka az volt, hogy rendben legyen a gyerek. Azt mondta, hogy legyek építész, mivel nem nagyon tudtam, hogy mi legyek. Ez a szakma azért tetszett meg nekem, mert azt gondoltam, hogy régi épületek közé új épületeket fogok tervezni, harmóniát teremtek, ami az embereknek hasznos, és ez milyen jó dolog. Azoknak, akik ott laknak, milyen jó lesz, mert az épület maga sugallja majd ezt a harmóniát. Utána pedig kiderült, nem nagyon tudok rajzolni. A szabadkézi rajz nekem nem nagyon ment, így építőmérnöknek vettek fel, aki a statikus (szerkezeti) dolgokat csinálja, ami messze nem az, amit én szerettem volna. Igen ám, de ez egy olyan időszak volt, mikor „sínek voltak, de váltók nem”. Akkor nem lehetett azt mondani, hogy bocs, én most átmegyek egy másik egyetemre, vagy egy másikat is el akarok végezni. Akkor azt kellett befejezni, amit elkezdtél. Minden „egyebet” csináltam az egyetem alatt, s ezért minden létező vizsgán meg is buktam - én, a kitünő tanuló -, most gondoljátok meg, ezt pszichésen feldolgozni elég nehéz volt. Ugyanakkor jelentős személyiségfejlődést jelentett nekem ez az időszak. Mindenhova jártam: színházba, moziba, rengeteget olvastam, zenét hallgattam, és a magyar társadalom rétegszerkezetét leképező számos szociológiai kutatásban vettem részt, elég tudatosan. Az egész magyar társadalomról lett így - kérdezőbiztosként, kezdő tanulmányíróként - egy jól kialakult képem. Volt elképzelésem arról, hogy hogyan élnek a cigányok, a fogyatékossággal élők, a melósok, a kőgazdagok. Tudtam angolul - akkoriban nem sokan tudtak -, és nagyon sok mindent annak köszönhetek az életemben, hogy tudtam. Konferenciákra mehettem, meg tudtam érteni mindazt, amihez nyelvtudás kellett, volt tehát egy helyzeti elönyöm. Egyszer például ültem a Műszaki Egyetem könyvtárában, és a Time Life Magazin vasárnapi számát olvasgattam, ami ugyebár nem egy természetes müszaki egyetemista dolog volt, abban az időben meg pláne nem. Azt látom a címlapon, hogy a rendőrök verik a Mikulásokat. Tehát ott volt a címlapon egy Mikulásruhába öltözött ember és egy rendőr, aki gumibotozta a Mikulást. Elkezdtem olvasni, és akkor kiderült, hogy ez Christianiában, Dániában történt. Akkoriban ott létezett a világ legérdekesebb alternatív életformája. Régebben amerikai katonai bázis volt, és az amerikai katonák kivonulásával egy független, kísérleti, közösségi életmód alakult ki ott. S amikor a koppenhágai önkormányzat ki akarta tenni öket, akkor a konszolidált polgárok élöláncot alkottak, és nem engedték kitenni az ott élőket. Volt a történelemnek egy olyan szerencsés időszaka, mikor a társadalom azt mondta ezekre az alternatív életformát élö „idióták”-ra, hogy amit ti csináltok, az nekünk ,átlagembereknek” is fontos, mert az a szabadság modellje, és ha ti ezt meg tudjátok csinálni, az azt jelenti, hogy mi is szabadok vagyunk, és ezért szolidárisak vagyunk veletek. Ezt aligha tudnám elképzelni itthon. A Mikulás-verés pedig úgy történt, hogy 
volt egy színjátszó csoportja Christianiának, akik folyamatosan csináltak színházi előadásokat. Abban az évben azt találták ki, hogy rengeteg Mikulás-ruhát varrtak, bementek a városba és elözönlötték az üzleteket, Mikulás-szerkóban. Benyúltak a polcokra, és odaadták a vásárlóknak a tárgyakat, az árukat (pl. rádiókat, televíziókat), hogy „ez a Mikulás ajándéka”. Ebben a gesztusban volt polgárpukkasztás is, volt baloldaliság is (hogy a fogyasztói társadalom extraprofitjából egy mákszemnyit visszaosztunk a társadalomnak). Ez nekem nagyon tetszett, hogy így is lehet élni.

Még mérnökként írtam egy dolgozatot a hatvannyolcas diákmozgalmakról, meg az ahhoz kapcsolódó eseményekről, és kaptam rá egy csillagos ötöst, mert akkor tudományos szocializmust és mit tudom én miket kellett tanulni. Kilencvenben egy ösztöndíjjal kijutottam Baltimore-ba, és ott elmentem egy moziba. Egy olyan dokumentumfilmet vetítettek, ami a '68-as diáklázadásokról szólt, és hihetetlen érdekes szivárványként elöadta az egészet, hogy hogyan függ össze a Fekete Párducok mozgalma, a feminista mozgalom, a zöld mozgalom meg a többi. Akkor megértettem, hogy az a dolgozat, amit én írtam, abból egyetlen árva szó nem volt igaz, pedig amikor én azt megírtam, akkor azt gondoltam, hogy az összes létező magyar forrásmunkát elolvastam, és eszembe sem jutott az, hogy ez mind csak propagandaszöveg volt.

Igen ám, de ahhoz, hogy én Christianiába menjek - mert nagyon elhatároztam, hogy oda megyek -, azt a döntést kellett volna meghoznom, hogy örökre elhagyom Magyarországot. Ezt pedig nem akartam. Viszont ettől kezdve hihetetlenül sokat utaztam. Év közben kubikoltam, nyáron meg elutaztam azt a pénzt, amit év közben kerestem. Akkor háromévenként lehetett Nyugatra utazni, és egész kevés valutát lehetett csak kiváltani - azt az egy hónapra való pénzt kerestem meg év közben.

$[\ldots]$

A Civil Rádiónak egyik alapítója vagyok, a Szociális Munkások Magyarországi Egyesületének akkori elnökeként. Az első időszakban én voltam a stúdióban csütörtök délutántól éjfélig. Az egyik müsor, amire a legbüszkébb vagyok, azt a nevet viselte, hogy „Barátságkenyér”. Voltak akkoriban ezek a lehúzós pilótajátékok, én ezeket átfordítottam pozitívba. A barátságkenyér olyan, mint egy püspökkenyér, bemész a spájzba, minden finomat beledobálsz egy tálba, összekevered, vársz és kész. A müsor pedig arról szólt, hogy az egyik ember 15 percig a másikat dicséri. Elmondja, hogy miért szereti, miért tiszteli, mit becsül benne. Ma is könnybe lábad a szemem, ha erre visszagondolok. Ugyanis az, hogy belénk rúgnak, hogy a hátunk mögött rosszat beszélnek, hogy intrikálnak - ezt természetesnek vesszük. De azt, hogy dicsérnek, azt nem. Komoly érzelmek szabadulnak fel ilyenkor. A müsor arról szólt, hogy valaki megkapja a barátságkenyeret, majd a következő müsorban ő adja tovább. Azt hiszem, 32 adást ért meg ez az ötlet, és Urbanekné László Judit volt az első, ha a neve mond még nektek valamit. Ö találta ki a családsegítő szót, a Minerva Családsegítő Szolgálat vezetője volt - eredetileg könyvtáros. Szociális szolgáltatásokat illesztett, szervezett össze, ez volt az ő szolgáltatásának a lényege. Amikor a Tudományos Akadémia megcsinálta az emlékezetes devianciakuta- 
tást $^{1}$, és annak eredményeképpen létrejött az első családsegítő szolgálat (amit én vezettem), akkor a javaslattevők Urbanekné László Judit ötletét húzták be, és a családsegítő nevet vették át Judittól.

A következő etapban arról szeretnék beszélni, hogy kik azok, akik nekem szakmai szempontból fontosak voltak. Az egyik, aki nekem a legfontosabb volt, az Saul D. Alinsky. Az ö fö tételmondata az, hogy ,,[t]edd azt, amit tudsz, azzal, amid van”. Hihetetlenül egyszerü. Ha azt kérdezitek, hogy milyen identitásom van, azt mondom, hogy közösségi szociális munkás vagyok. Alinsky közösségszervező volt Amerikában, az ő Radikálisok kiskátéja címü könyvét tudom ajánlani. Akitől kaptam ezt a könyvet, egy dél-afrikai szociális munkás volt, aki itt a tanszéken ${ }^{2}$ tanított. Éppen selejtezték a könyvtárat, ki akarták dobni, akkor azt mondta, hogy „Géza, ezt olvasd el, mert téged ezek a közösségi dolgok érdekelnek”. Alinsky egy baloldali figura volt, de ha a direkt politikát kivonjuk a szövegböl, akkor egy nagyon jó közösségi szociális munka tankönyvet kaphatunk belöle. A dologban az a hihetetlen, hogy ezt a kötetet először a Müszaki Egyetem gépészkarának KISZ-szervezete adta ki, 1988-ban ${ }^{3}$. Azért lehetett annak idején kiadni, mert a fordító belerakott Marx-, Engels- és Lenin-idézeteket a szövegbe. Mikor ezt először olvastam, akkor nem is vettem észre, hogy ez a fordító leleménye. Ugyanis, ha ezeket az idézeteket nem rakja bele, akkor a könyv valószínüleg meg se jelenhetett

volna.

De mit is jelent ez a cím? Ha segítőként kliensekkel, klienscsoportokkal dolgozol együtt, akkor az egyik legfontosabb pont az, hogy a közösségszervezőnek valaki azt mondja, hogy: „Kérem, én nem tudok segíteni, mert nincs eszközöm. Mivel változtassak?” Erre az a válasz, hogy: „Nem kell messzire menni. Nézd meg, hogy ahol most vagy, ott milyen eszközöd van. Mindenkinek van eszköze." Alinsky hihetetlen optimizmusa, hogy nincs olyan pillanat az életben, amikor semmilyen eszközöd ne lenne. Erre egy gyönyörü példa az, hogy tartott egy előadást egy meglehetősen konzervatív, egyházi egyetemen Amerikában, ahol nem lehetett csajozni, hangoskodni, bulizni. A hallgatók nagyon boldogok voltak az előadásától, de azt mondták, hogy ök ezt bizony nem tudják alkalmazni. Amerikában az előadásokon minden hallgatónak jár a szája - rágógumizik. „Ezek szerint »valamilyen eszköze« mindenkinek van - mondta Alinsky -, van rágógumija! Akkor adjanak egy csomag rágógumit, és én megállítom Chicago forgalmát." Az amerikai campusokon egy bejárat van: sorompó fel, bemegy az autó, sorompó le. „Vegyenek egy csomag rágót, kezdjék el rágni, aztán köpjék oda a sorompó alá. Meglátják, mi lesz.” Egy hónap múlva kap egy levelet, hogy: „Megcsináltuk. Most már lehet sörözni, csajozni, bulizni, hangoskodni. Csak egy dolgot nem lehet: rágógumizni.” Az egy nagyon fontos gondolat, hogy ha az emberek úgy érzik, hogy nincs hatalmuk a dolgokon változtatni, akkor nem fognak azon gondolkodni, hogy mit csináljanak és hogyan. Tehát hatalmat kell adni az embereknek.

Nem meséltem még, hogy az életem további alakulását a szociológia határozta meg, ennek pedig központi fogalma a hatalom. És a hatalom nemcsak politikai hatalmat jelent, hanem mindennapi szinten is jelen van. Az is hatalom, mikor a kisgyerek a papát meg a mamát egymásnak ugrasztja. A hatalom birtoklásának már a valószínüsége is megmozdítja az embere-

\footnotetext{
${ }^{1}$ A „Társadalmi Beilleszkedési Zavarok” (TBZ) c. kutatást.

${ }^{2}$ Akkor ELTE Szociológiai és Szociálpolitikai Intézet, Szociálpolitika és Szociális Munka Tanszék.

${ }^{3}$ Majd A civil szervezkedés ábécéje (Rules for Radicals) címmel a Bagolyvár Könyvkiadó, 1999-ben.
} 
ket. Kínában a Tienanmen téren, egy katonai rezsimben, egy ember odaállt a tankok elé, és megállította a tankokat, ami egy teljesen valószínütlen vállalkozás volt. Azóta ez a fotó bejárta a világsajtót, és annak a szimbóluma, hogy egy ember is tehet valamit. Ezt a pontot kell megtalálni, hogy mindenki elhiggye, hogy ő egyedül is tud valamit tenni, de ha összeállnak, akkor még többet tudnak tenni.

Ha a magyar szakmai mintákat nézem, akkor Ferge Zsuzsát kell említenem - mindannyian az ö köpönyege alól bújtunk elő -, az elszabaduló egyenlőtlenségek gondolata hatott rám leginkább.

Mezei Gyuri ${ }^{4}$ a másik, aki cigányügyben volt igazán otthon, sokat dolgoztunk együtt az első családsegítőben. Én inkább a volt állami gondozottakkal foglalkoztam.

Eddig is inkább sztorikat mondtam nektek önéletrajzként, ezután is így próbálom elmondani. Azzal folytatnám, hogy a Szociális Munkások Magyarországi Egyesületének is az alapítója voltam. Ennek persze ma már túl nagy jelentősége nincsen, de ez volt az ország második vagy harmadik valóban civil szerveződése. Elötte a Hazafias Népfront működött átfogó civil szervezetként, és az ágazati minisztériumhoz kellett bejelenteni a civil szervezet megalapítását, nem a bíróságnál. Ez egy fergetegesen jó és lelkesítő időszak volt mindenki számára. A mai viszont kiábrándító. Aztán benne voltunk a Humán Szolgáltatók Nonprofit Egyesületében, az is próbált ernyőszervezetté válni, még a Szociális Szakmai Szövetség előtt. Aztán kettévált - politikai alapon - a magyar civil társadalom, amit én nagyon sajnálok, és egyre nehezebben viselem. (Nekem van egy 20 fős baráti társaságom, van köztük mindenféle beállítódású ember, tíz éve minden hónapban elmegyünk együtt színházba, utána kocsmába, és megváltjuk a világot... De az ilyen nagyon ritka, nem is tudok más, ennyire vegyes csoportról. Büszke is vagyok rá.)

Nyolc évig voltam a Fővárosi Szociális Közalapítvány önálló jogi személyiséggel rendelkező szervezeti egységének, a Budapesti Szociális Forrásközpontnak a vezetője ${ }^{5}$. A Forrásközpont első megbízása a Híd Családsegítő szakmai értékelése volt. Akkoriban ez volt az egyetlen családsegítő szolgálat, amely egyházi alapon müködött. A megbízó XIII. kerületi önkormányzat azt gondolta, hogy majd rossz minősítést fogok írni róluk, és akkor saját kézbe vehetik a katolikus egyháztól, de a Hídban kiválóan dolgoztak, és én ezt is írtam le. Az intézmény vezetője Tomcsányi Teodóra volt, akinek férje, Csáky-Pallavicini Roger épp akkor írta az egyházi szociális munkáról a szakdolgozatát. Egészen addig én azt hittem, hogy van egyházi szociális munka, de azóta azt gondolom, hogy nincs (csak egyházban végzett szociális munka, hasonlóan a kórházban/utcán/börtönben/stb. végzett szociális munkához). Én ezt Philadelphiában értettem meg, ahol a város főterén minden évben egy karácsonyfát szoktak felállítani. Abban az évben a helyi zsidó közösség kijárta, hogy Hanuka idején egy menórát állítsanak fel. Én a hajléktalan szektort néztem meg Amerikában, és nem értettem, hogy miért van az, hogy néhány szolgáltató egyetlen állami fillért sem kap. Pedig rengeteg egyházi szervezet van. Az egyik ilyen például úgy müködött, hogy egy hatalmas teremben kiraktak minden este egy Biblia-idézetet, gyönyörü, archaikus nyelven, ami persze nagyon

\footnotetext{
${ }^{4}$ Mezei György (1953-2006) szociális munkás, az Újpesti Családsegítő Központ, a Menhely Alapítvány, a Twist Olivér Alapítvány alapítója.

${ }^{5}$ Az intézmény 1995-2015 között müködött.
} 
messze állt a hajléktalanok világától. Az a hajléktalan, aki megtanulta, és háttal a kiírásnak el is tudta ismételni, az kaphatott szolgáltatást. Ha nem tudta még elég jól, a következő sorban lévők (akik szemben voltak a szöveggel), súgtak neki. És ezt mindenki tudta, hogy így zajlik. Az adott egyházi szolgáltatók ugyanis azt gondolták, hogy ha valaki egy bibliai idézetet megtanul, akkor jobb ember lesz. S ha ezt megtette, akkor kapott szolgáltatást. No és ezért nem kapott ez az intézmény egyetlen állami petákot sem, mert a térítés nem lehet a szolgáltatás előfeltétele.

A Moszkva téren az Üdvhadsereg rendre megénekelteti a hajléktalanokat, mielött levest oszt - ez Amerikában nem lenne lehetséges. Ha viszont a levesosztás után a hajléktalan odamegy valamelyik levesosztóhoz, és azt kérdezi, hogy van-e túlvilág, és erröl elbeszélgetnek, az már teljesen rendben van. Ez a sorrend egy nagyon fontos dolog, amit itthon nem nagyon értünk. $\mathrm{S}$ ez az, ami elöjött a philadelphiai menórával kapcsolatban, hogy a vallás az ember magánszférájába tartozik, nem a közszférába. Szerintem is. De itthon ezt nem így tartjuk.

Időben ugrabugrálva mesélek, mert eredetileg mérnök voltam, épületek is örzik a kezem nyomát. Mikor a müemléki osztályon dolgoztam, az nekünk fontos szempont volt, hogy aki a felújítandó épületben lakik, az jól érezze magát, s emiatt mindig késtünk a határidőkkel. Megcsináltuk a terveket, aztán elkezdődtek a munkák, és nem az költözött vissza, aki előzőleg ott élt, nem az a cég költözött vissza - kezdhettük elölröl. Ma például van a Világörökség napja, egy évben egyszer, amikor meg lehet nézni egyébként zárt épületeket. Ilyenkor egyegy ember elmondja tanúságtétel-szerúen, hogy miért akarta azt megépíteni/felújítani. Ez a „szolgálat” vitt engem a szociológiába is, és a szociális munkába is. Az építészetben is egy határterületet vittem, az építészet leghumánabb oldalát. Olyan módon dolgoztunk a müemléki osztályon, hogy ott együtt dolgozott a gépész, a statikus, a müvészettörténész, és ez fantasztikusan jó volt. Ezek az élmények nagyon alakítottak. Amit ott megtanultam, és később hasznosítottam, hogy a határterületekkel lehet a legjobban pályázni. Ahol kell a mérnöki tudás, a szociológiai tudás, a szociális munka, a közösségi munka... De Magyarországon nincs sok olyan munkakör, ahol minderre egyszerre van szükség, pedig ezek érdekes munkák, és leginkább generalista módon lehet megközelíteni pl. egy városrehabilitációs vagy egy romatelepfelszámolási feladatot.

A Szociális Forrásközpont is ilyen volt, nagyon sokféle projekttel. Kutatás-tervezés-oktatás, idősek-gyerekek, mindenféle határterületi dolog. Mindig nagyon fontos volt az innováció az életemben. Nekem mindig kellett az, hogy valami olyan dolgot csináljak, amit még senki más. Hála Istennek, az én életemben ezt meg lehetett csinálni. A forrásközpontban is meg lehetett csinálni, a családsegítőkben is, mivel azok induló intézmények voltak, ott lehetett kísérletezni. Ma már ez nehezebb. Az első családsegítőben az első közösségi projektet tömbözésnek hívtuk. 15 önkéntessel dolgoztunk együtt. Mikor megnyílt a családsegítő, fogalmunk se volt, hogy mit is kellene csinálni. Ekkor tanultuk meg például azt is, hogy az önkéntesség milyen nehéz dolog. Az egyik önkéntes a szomszéd kerület gyámhatóságán dolgozott, és ahogy járt lakásról lakásra, látta, hogy az egyik egyedülálló anyánál mindig más férfi van. Elment a rendőrségre megkérdezni, hogy tudják-e, hogy ez a nő prostituált. Ekkor értettük meg, hogy az önkéntesek alkalmazásához bizony nagyon sok időráfordítás kell. Foglalkozni kell az önkéntessel, az nem úgy van, hogy megnyomom a gombot, és akkor ő önjáróként elintézi a saját feladatát. Képezni kell. 
Azóta az önkéntesekre már egész szervezethálók épülnek fel, de én úgy emlékszem erre a történetre, ami az egyik legmegrázóbb esete.

A tapasztalati szakértő projektet hoztam legutoljára. Tegnapelőtt kaptuk rá a SozialMariedíjat, Bécsben. Miért Bécsben? Az Európai Szegénységellenes Hálózat felkérte a Szociális Szakmai Szövetséget, hogy Brüsszelbe vigyen ki öt szegény embert, mert a hálózatban azt találták ki, hogy az asztal egyik oldalára odaültetnek minden országból öt szegény embert, velük szembe meg Európa vezető politikusait. Akkor azt gondoltuk magunkban, hogy ezeknek elment a józan eszük, és azt mondtuk, hogy nem. De a csepeli családsegítő akkori vezetője, Aczél Ágnes zseniális ötlettel állt elö. Ferge Zsuzsának volt akkor egy szegénységkutatása, rengeteg interjút csináltak, megvolt még velük a kapcsolat, hát vigyük el öket Brüsszelbe. Ennek az öt embernek az életében, akit kiválasztottak, minden létező szociális, szociálpolitikai probléma benne volt. Minden résztvevő a saját nyelvén beszélhetett, 18 nyelvre ment a fordítás, hihetetlen pénzbe került, de ez volt az az eszköz, amitől a dolog remekül müködött. Ekkor az egyik résztvevő azt mondta, hogy: „Miért dicsőség bizonyos társadalmi szint felett, és miért szégyen bizonyos társadalmi szint alatt sok gyereket szülni?" Zseniális kérdés, amit ő nyilván azért tudott megfogalmazni, mert számtalanszor megkapta szegény emberként, hogy miért szüli azt a sok gyereket. Azt hittem, hogy ez hungarikum, vagy legalábbis keleteurópai jelenség. Ehhez képest mindenki értette és mindenki bólogatott, tehát náluk is így van. Tehát ez a szegénységben élő asszony (Pletser Ágnes) seperc alatt feltett egy olyan kérdést, ami szociálpolitikai szempontból egész Európában releváns. Egy másik ott ülő szegény pedig azt kérdezte, hogy: „Miért van a kígyóuborka hajlásszögére európai sztenderd, a szociálpolitikáéra meg miért nincsen?” Zseniális! Ö ezt két brüsszeli nap alatt észrevette. A vacsoránál ültünk az első belga „tapasztalati szakértő”-vel, aki egykori szegény emberként már a minisztériumban dolgozott 8 órás munkában, teljes fizetéssel. Megpróbáltuk ezt megcsinálni itthon is, a Norvég Alap támogatásával. Volt egy nyolc hónapos képzésünk, hétvégenként. A belgák sokkal hosszabban képzik a saját embereiket, de a miénk is fantasztikusan nagy dolog volt.

Az egyik tapasztalati szakértőnk egy olimpiai kerettag bokszoló volt. Mint egy háromajtós szekrény. Szerintem ivott, ezért nem vitték ki az olimpiára, és emiatt a sportkarrierje kettétörött. Elment behajtónak, ami még neki is borzasztó, erőszakos meló volt. Elvégzett egy csomó OKJ-s tanfolyamot, többek között volt szakács is. Ma azt csinálja, hogy összegyüjtik a Tescóból meg mindenhonnan a lejáró kajákat, és abból valami csodákat főz, és azt viszi ki ételhordóban a szomszédoknak. Abban a kerületben szerencsére elég jó az önkormányzati szociálpolitika, de ő - lokálisan - messze túltesz rajta. Ha nem látom a két szememmel, nem hiszem, ahogy ott ül ez az ember a pincekocsmában, és osztja az igazságot, mint Mátyás király, és rendet tart a környéken. Ugyanezt láttam Belgiumban is: egy ember, az egész testén tetkóval, az idegenlégiót megjárta, szintén ezt csinálta. És ez egy nagyon érdekes kérdés, hogy ez hogy lehet. Ennek a rutin formája a megtérés. Ha kivesszük az ember kezéből az alkoholos üveget vagy a drogot, akkor üres marad a keze. Valamit bele kell rakni (átvitt és konkrét értelemben egyaránt), nem hagyhatjuk üresen. Ez az ember azóta megcsinálta a „Szegények szakácskönyvét”. Ha nincs ez a projekt, neki sem jutott volna eszébe. Ma áruházakban árulják a könyvét és a videóját. Ezért jó ez a projekt, hogy e kettő össze tudott találkozni. 
A másik tapasztalati szakértős történet egy kisvárosban történt. A kolléganő, aki az előző népszámláláson dolgozott, felajánlotta, hogy a szegénynegyedekbe, cigánynegyedekbe elmegy kérdőívezni. A jegyző, aki szervezte a népszámlálást, kérdezte, hogy kér-e segítséget, mondja, hogy nem, aztán mégis hagyja magát meggyőzni. És amikor megy a telepre, akkor megáll egy mikrobusz a megbeszélt helyen, kiugranak belöle símaszkos emberek, és a parancsnok azt kérdezi tőle, hogy: „Ön a védendő személy?” Nos, az az ember, aki szervezte a népszámlálást, vajon mit tudott a szegénységről, a cigányságról? Valószínüleg semmit. Mint jogász - tudományos oldalról - nem kapott semmit se erről. Azóta a KSH-ban ez már átment, hogy a tapasztalati szakértők tudnának valamit hozzáadni ahhoz, hogy a nagyon szegények körében hogyan lehet lekérdezni kérdőíveket, mert azt a KSH-ban is érezték, hogy valami nem stimmel a legalsó társadalmi rétegekben kapott adatokkal.

Egyet még elmondok: a Gyerekszegénység Elleni Programot. Ott a tapasztalati szakértőt nem így hívták, hanem iskolai koordinátornak. Egyikőjük egy helyi cigány asszony volt, aki a helyi iskolában dolgozott. Józsika (nevezzük így) aznap, amikor ott jártunk, nem jött iskolába, erre kiment hozzá a tapasztalati szakértő, és kérdezte az otthon lévő anyukáját, hogy Józsika miért nem jött iskolába. „Kinn van az erdőben, fát vág - felelte az asszony -, ugyanis az apuka nem tud fát vágni, mert börtönben van falopásért." Kérdés, hogy hogyan lehet ezt a helyzetet kezelni?

Többféleképpen:

(a) Mikor visszamegy az iskolai koordinátor, elmondja a történetet, és a pedagógusok leigazolják a hiányzást.

(b) De ugyanakkor azt is megnézhetik, hogy csak ennél a családnál van-e ez a probléma. Vagy másnál is? S ha igen, akkor nem kéne-e az önkormányzatnak például fát osztania a szegényeknek? Van, ahol ezt nem lehetne megcsinálni, máshol igen. (c) Önkormányzati tulajdonban lévő erdőkből le lehetne kanyarítani egy darabot, ahol a szegények erdőgazdálkodást folytathatnának, tehát nemcsak elvinnék a fát, hanem telepítenék is. S ennek érdekében akár segéderdészképzést is kaphatnának, ami a munkaeröpiaci helyzetükön is javíthatna. De addig, míg mindezen sokféle fejlesztés kigondolását a szociális munka részének tekintik, még sok víznek kell lefolynia a Tiszán.

Körülbelül ennyit akartam bevezetésként elmondani. Munkánk során készítettünk egy csomó kiadványt is, honlapot is, amelyek általában újdonságot jelentettek annak idején: drogról, szupervízióról, a bevásárlóközpontok társadalomátalakító hatásáról, társadalmi célú reklámról, örökbefogadásról, internetes zaklatásról, a szociális munka és a különféle társszakmák kapcsolatáról stb. Szociális munka-e mindez? Én azt gondolom, hogy igen. Pik Katival megszerkesztettük a Szociális munka szótárát. Ma már persze teljesen elavult, hiszen ma már csak interneten szabad ilyent csinálni, folyamatos frissítéssel. Amit pedig tegnapelőtt láttam a SozialMarie-projektben, a legérdekesebb az volt, hogy hajléktalanok tartottak városvezetést, az ő szemszögükből mutatták be a várost.

Még nagyon sokat tudnék mesélni, de inkább kérdezzetek.

Kérdés: Hogy tud ez a baráti társaság, amit említettél, ilyen jól müködni? 
G. G.: Talán nem szerénytelenség, de nagyon sokat dolgozom vele, hogy ne menjenek szét barátságok politikai okok miatt. Lehetnek ilyen kis szakmai körök is. Mivel én különböző szakmákban dolgoztam, így különböző szakmákban vannak ismeröseim. Öket kötöm össze úgy, hogy a tolerancia megmaradjon. E szemléletem gyökerét azt hiszem, édesanyámban találnám meg, aki zöldkeresztes nővér volt, és vitt engem barlanglakásokban élő családokhoz, de közben soha azt a szót ki nem mondta, hogy szegénység, csak tette a dolgát. A Zöldkeresztes Védőnői Szolgálat egy Rockefeller Alapítvány volt a háború előtt (1927), ott a védőnök szociális képzést és egészségügyi képzést is kaptak. A háború után az orvosok ezt átalakították gyakorlatilag orvosi asszisztenciává, és szinte teljesen kihagyták belőle a szociális részt.

Kérdés: És ugyanez a sokféleség szakmai civil szervezeti szinten hogyan valósulhat meg?

G. G.: Én a Szociális Szakmai Szövetség továbblépését is abban látnám, hogy valami olyan szervezetté váljon, hogy a 6000 magyar szociális szervezet kapcsolódni tudjon hozzá. De a jelenlegi vezetés csak az elitet, a szakképzetteket akarja képviselni. Szerintem ez nem jó. Volt olyan pillanat, mikor kellett mindenki (a megalakulás idején), de ma már nem ez a főcsapás iránya. Ferge Zsuzsa álláspontja az volt, hogy a szociális munkást egyetemi szinten kell képezni, hogy partnernek tekintsék a többi egyetemi végzettséget igénylő szakmák. Én Londonban azt láttam, hogy ez egy föiskolai szintü képzés, ami sokkal jobban müködött, mert gyakorlatorientált volt. Természetesen kaptak mindenféle elméleti képzést, de föiskolai szinten. Ugyanakkor Zsuzsa érvei fontosak itthon, és erről még sokat lehetne beszélni. A szakmai sokszínűséget igyekeztünk a HÁLÓ-ban (a Szociális Szakmai Szövetség folyóiratában) is megjeleníteni, míg én szerkesztettem ${ }^{6}$.

Kérdés: Hallottam a „Szociális munkás I. + Szociális munkás II.” modellről. Mi volt ennek a lényege?

G. G.: Az első családsegítőben, a terézvárosiban kísérleteztünk azzal, hogy volt egy kolléga (Szociális munkás II.), aki sok időt ott töltött a családdal, tanította őket az alapvető háztartásvezetési dolgokra, gyakorlati segítséget nyújtott, a párja (Szociális munkás I.) meg mentálhigiénés beszélgetéseket vezetett, mondjuk egy héten egyszer. A különböző segítségeket másmás embertől kapta meg egy család. Amerikában láttam olyan családot, ahol ki volt ragasztva a család kapcsolatrendszere egy évvel ezelött és most. Kikkel van kapcsolatban, milyen szervezetekkel. Hihetetlenül boldog volt a mama - fekete, termetes asszonyság -, aki mutatta, hogy mennyivel több kapcsolata van, a szociális munkás segítsége miatt. Ezt szeretem a szociális munkában, hogy ilyen hihetetlenül egyszerü eszközökkel lehet eredményeket elérni. 